\title{
Design Driven Innovation as a Differentiation Strategy - in the Context of Automotive Industry
}

\author{
Mosarrat Farhana', Eric Bimenyimana ${ }^{2}$
}

\begin{abstract}
Though, in the automotive industry, technology is considered as a source of innovation and development, emerging change in consumer perception has brought industry focus on design. Evolution of this industry is closely related to the convergence of technology and design. In such context, implication of design driven innovation strategy in the automotive industry has potential to be explored and to create sustained competitive advantage through balancing customers' need, technological opportunities and product meaning. The aim of this paper is to give a holistic view of design driven innovation as a differentiation strategy in the automotive industry and its implication for strategic management through some relevant research reviews and empirical information. On the contrary, this research lacks detailed description on industry practice to provide greater breadth, since it attempts to correlate the strategic concept of design with the dynamic capability of a firm in that particular industry.
\end{abstract}

Keywords: dynamic capability; design; innovation; competitive advantage; automotive industry.

\footnotetext{
1,2Division of Business Administration, Linköping University, Linköping 58I 83, Sweden. e-mail: 'mosarrat_58@yahoo.com (corresponding author).
} 


\section{Background}

The global corporate culture is entering into an era where overall look of product is considered as an essential part of competitive tools (Dobson, 2007). Aesthetic appearance of the product through design is valued as one of the ways to differentiate the offerings of the company (Ravasi and Lojacono, 2005). Nowadays, design is recognized as strategic resource for the company, since customers are increasingly paying attention to the design language, i.e. the combination of aesthetic, symbolic and emotional value of the product. Moreover, many scholarly research works have emphasized on the link between design, innovation and competitive advantage which shows up the rising attention of the industrial world towards design section (Dell'Era and Verganti, 2007). From this notion, a literature based bottomup analysis will be conducted to unfold the link between the strategic approach of design and the dynamic capabilities of the company in innovation process to achieve sustained competitive advantage; and later its managerial implications will be discussed. The aim of this paper is to relate aesthetic dimension of a product to the strategic thought on innovation and to analyze its contribution to achieve and to sustain competitive advantage within the contemporary business world. Thus, the theme for the paper is:

\section{'Design driven innovation as a differentiation strategy' in the context of automotive industry}

The evolution of the automotive industry can be characterized by the convergence of technologies and designs (Grant, 2010, p. 538). This pattern is sometimes expected to breakdown and open up for certain new radical departures due to the world economic situation and rising environmental concerns (Magnusson and Berggren, 20l I). Regardless of less differentiation between manufacturers due to same technological progress in process, new product segments have continued to appear for the innovation in design and applications (Grant, 2010, p. 538-539). In such context, as an integral part of this research work, relevant empirical examples will be placed based on the automotive industry.

\section{Design - a resource for competitive advantage}

"Good design is not simply about aesthetics or making a product easier to use. It is a central part of the business process, adding value to products, and creating new markets."

$\sim$ The British Prime Minister, Tony Blair (as cited in Dell'Era and Verganti, 2007, p.3)
A product can bring messages to the market in several ways where the aesthetic appearance of the product is just one of these ways to satisfy customers' needs (Dell'Era and Verganti, 2007). Many research works have revealed that whenever people are asked to think about peculiar nature of design considering other fields such as engineering, they think of the product form, spelled as 'aesthetic' and 'style'. Design deals with the meanings that people give to products, and also with the product languages that one can devise to convey that meaning (Verganti, 2008).According to Krippendorff (as cited in Verganti, 2008) - "design is making sense (of things)". Designers give meaning to products by using a specific design language, which refers to the set of signs, symbols and icons to convey the message (Verganti, 2008) and to match socio-cultural models of the user (Dell'Era and Verganti, 2007).

In the design of products, companies are manipulating the material parts of their products with the hope that customers will decode the meaning carried by those products; these particular actions have been referred to as the "meaning-making actions" by Hancock (2005). This observation is also acknowledged by Per Åman, Professor of Department of Management and Engineering at Linköping University, Sweden. For example, in its production, the Swiss watchmaker Rolex uses a special type of steel904L ("Rolex", n.d.) with a clear goal of signaling good quality to customers.

Scholarly research defines competitive advantage within a firm as "implementing a value creating strategy not simultaneously being implemented by any current or potential competitors" (Barney, |99I). Mooney (2007) defines competitive advantage as "a capability or resource that is difficult to imitate and valuable in helping the firm outperform its competitors". As Grant (2010) acknowledges, the role of industry attractiveness as the primary source of firms' profitability has decreased due to deregulations and increased international competition. Thus, scholars and managers have turned their attention to the role of competitive advantage as the primary source of profitability (Grant, 2010, p. 124).

In the last decade, researchers have observed the rising trend of design based strategy as a competitive advantage in different industries where companies have reinforced their positions through product design. For example, innovative and lifestyle-oriented bold product design has positioned Nokia, Sony, Philips and Apple as valuable global brands and also has revitalized these high-tech brands to meet customers' latent demands (Ravasi and Lojacono, 2005).

A firm's possessed competitive advantage becomes sustained competitive advantage while "[...] other firms are unable to duplicate the benefits of this value creating strategy" (Barney,

ISSN: 07 I8-2724. (http://www.jotmi.org) 
1991). For example, Ducati- the Italian motorcycle brandis famous because it represents Italian industry across the globe through the authentic Italian style expressed in the design of each bike ("Ducati", 20I2) Here, technology can be imitated by others at certain level but the authentic design of the product is difficult to be copied and becomes a firm's sustained competitive advantage.

\section{Innovation \\ - an integral part of dynamic capabilities}

Teece, Pisano and Shuen (1997) have stated in their research work:

We define dynamic capabilities as the firm's ability to integrate, build, and reconfigure internal and external competences to address rapidly changing environments. Dynamic capabilities thus reflect an organization's ability to achieve new and innovative forms of competitive advantage. Several research scholars such as Teece, Pisano and Shuen (1997), Bowman and Ambrosini (2003), Zollo and Winter (2002), Zahra and George (2002), Eisenhardt and Martin (2000) have discussed certain key propositions of the dynamic capability view; where mostly have reckoned its role in leveraging firm's resources to craft new business and to introduce innovation to stimulate any strategic change in congruence of rapid external change. Emergent research works and literature on the terminology 'dynamic capabilities' have focused immense importance on its application to ensure a firm's sustained position within the rapidly changing industry and global economy. Basically dynamic capability refers to a firm's unique ability to achieve sustained competitive advantage and profitability (Teece, Pisano and Shuen , 1997; Barney 199I) which depends upon the firm's specific and unique process and routine coupled with historic path and tradition (Zollo and Winter, 2002). A firm's operational capabilities encompasses its learning process, transformation of innovation process and thus the term dynamic innovation capability is evolved (Zollo and Winter, 2002; Davenport, Leibold and Voelpel, 2006). Once a firm has achieved it's dynamic innovation capability, it starts to invest ample resources on product development (Afuah, 2002). The result is either an incremental innovation i.e. minor changes in existing technology and performance; or breakthrough innovation, like new technology or greater customer benefits related to existing offer (Chandy and Tellis, 2000; O'Connor and De Martino, 2006; De Visser et al., 2010). At this point, it is evident in several research works that once companies become successful due to certain resource, their natural tendency motivate them to exploit it repeatedly and thus they often get crashed by sudden counter-attack/s (D'Aveni, Dagnino and Smith, 2010; Prahalad and Hamel, 1990). In another stream of strategic management research, this disruptive or rapidly changing dynamic market has been defined as 'hypercompetitive' market by researcher RichardA.D'Aveni (D'Aveni, 1998), who along with other researchers have questioned the existence of 'sustained' competitive advantage (D'Aveni, Dagnino and Smith, 20I0). According to their research works (D'Aveni, Dagnino and Smith, 20I0), sustained competitive advantage is rare and declining and is being substituted by temporary advantages to face hyper-competitors' aggressive actions. While different researchers have left ongoing debate on the coexistence or mutually exclusive existence of sustained competitive advantage and temporary advantage, it has been agreed that in either way dynamic capability is crucial for a company's survival in a fiercely competitive market (D'Aveni, Dagnino and Smith, 20I0). In today's buyers' type of market, longevity or sustainability of a competitive advantage largely depends upon company's dynamic ability in value creation and visioning for both existing and future customers through vigorous innovations and counter actions. The long term success of a company resides in satisfying relationship with its stakeholders i.e. customers and employees, which can be measured by in-depth qualitative research on the market along with basic sales trend analysis (D'Aveni, Dagnino and Smith, 2010; D'Aveni, 1998).

While dynamic capabilities have been heavily associated with innovation in rapidly changing technological industry (Teece, Pisano and Shuen, 1997; Grant, 2010, p. 158), the approach taken here is to understand how innovation of meanings is the next source of competitive advantage in a rapidly changing social and cultural environment. Indeed, as Ravasi and Rindova acknowledge the work of DiMaggio (as cited in Ravasi and Rindova, 2004), the fragmentation of cultures has led to an increase in demand for meaningful products that reinforce both the identities and the social status of consumers. This observation of fragmentation of cultures is reinforced by factors such as globalization where everyone is trying to hold on his or her identity in this competitive world. Even education also works as a major catalyst to define one's choice, such as consumers' preference for green products to support environmental cause.

Ravasi and Rindova (2004) have identified different resources and processes as required to attach emotional and symbolic value to products. Considering other scholars' opinions, they have agreed that product design is one of the essential tools used to produce symbolic value. Drawing on different theories in sociology and anthropology, they have identified different intangible assets needed in the production of meanings. Several research works on consumer behavior and anthropology of consumption have revealed that emotional and socio-cultural dimensions of consumption are as important as the utilitarian perspective (Verganti, 2008). Cultural capital, one of the important resources, is defined as "a firm's capability to grasp and decode cultural meanings" 
(Ravasi and Rindova, 2004). In other words, it is the capacity to discover new social and cultural trends in a society. According to Verganti (2003), in this social and cultural environment, designers' skills and competencies are mostly needed. Moreover, designers are involved in the production of meanings "through capturing, recombining, and integrating knowledge about socio-cultural models and products semantics in several different social and industry settings"(Verganti, 2003).

Verganti (2003) has called this type of innovation as "designdriven innovation" which he has defined as "an innovation in which the novelty of a message and a design language prevail over the novelty of functionality and technology". In order to recognize this design-driven innovation as a competitive advantage, he has stated that firms should possess superior capabilities among others that enable them to identify and influence "invisible" social and cultural trends. By invisible trends, he has referred to "socio-cultural phenomena that are not so visible now but will be trends tomorrow and reality in the future". In other words, these are new and unrevealed trends (Verganti, 2003). Since this innovation strategy is based on the research on consumer's latent demand or aspiration which could emerge in future society, this whole innovation process is quite challenging and risky for firms to some extent (Verganti, 2008; Verganti, 2009, p. 109). Moreover, sometimes this design-driven innovation takes time to diffuse within socio-cultural context and the users also need time to understand the proposed new meaning or language of the product (Verganti, 2008).

The evolution of automotive industry has played significant role in American socio-cultural change during the economic crisis and social conflict in the late 19th century. At that time automobile has entered the market with a symbol of class and luxury for upper class people. But later on GM's head Alfred Sloan and designer Harley Earl have brought change in the industry and the society by accommodating style in mass-produced vehicles for the working class people. The policy of GM has inspired other manufacturers to introduce different designs of car satisfying individual's aspiration and thus they have contributed to the social reform in the late 1920s (Gartman, 2004).

Ravasi and Rindova (2004) have done further research by proposing a way to integrate information about invisible trends. According to them, by building relationships with so called "lead cultures" - "community where certain social trends become visible ahead of the rest of the market" (Ravasi and Rindova, 2004), firms could gain advantages in grasping those unrevealed social and cultural trends. Once the firm is able to grasp those invisible trends and incorporate them into its product design; it will not only exceed customers' expectations but also influence this new phenomenon. For example, while women empowerment is in its rising peak in many developing or least developing countries like India, Bangladesh or Nepal, mobility for women has identified as one of the obstacles due to lack of social security. This social issue has been engrossed by the automotive company like TVS Motors Company and in 1994 they have pioneered mobility for women in India by launching TVS Scooty - specially designed scooter for women (http://www. tvsmotor.com). The scooters have not only moved women from the back of a motorbike to the driver's seat, but also repositioned women's social status with a segment of newly designed products (Brunson, 2013).

However, a critical issue should be addressed here which concerns the skills and competencies of designers as sustained competitive advantage. Barney (199I) concludes that a firm should meet four criteria in order to have sustained competitive advantage; its resources must be valuable, rare, inimitable and non-substitutable. Nowadays, designers have become internationally hunted and some of them are moving between firms. A good example includes the moving of Anne Asensio, former director of design at the French car manufacturer Renault to General Motors in May, 2000 (Bouchenoire, 2003).

\section{Interplay between two dimensions - Design and Innovation}

In technology-intensive industries, the quest for competitive advantage motivates firms to invest in innovation which in turn allow firms to dominate the industry (Grant,20 10,p.297). Though traditionally companies have considered technology as a source of innovation and development, in recent years they have shifted their focus on design. Design can improve products by making them more meaningful to customers, which in turn leads to significant growth and profit for the company. Because, when products are more meaningful, their perceived value to customers becomes high (Verganti, 2009 as cited in "Danish Design", 20I I, p. 16). Actually, engineers use technology to make products functional and designers use form to make products beautiful and meaningful to users to gives them (users) intangible psychological satisfaction and thus create difference in the market (Verganti, 2009, p. 20). Hence, technology can be imitated over time if it is not protected by copy right. But design is quite difficult and worthless to be copied considering associated brand value and customer experience. Unique and differentiating design of the product increases the competitiveness of a technologybased company to achieve sustained competitive advantage. Aesthetic and emotional value coupled with new meaning of a technological product not only secure competitive advantage but also give new experience to the customer; which is best expressed in the example of industrial designer Raymond Loewy's redesigned Sears's Coldspot refrigerator - transformation of a ugly and loud electric refrigerator of 
the time into an interior design machine to be kept in the kitchen in the year 1934 (Vogel, 2009).

According to Roberto Verganti (2008) there are three possible innovation strategies:

- Market-pull innovation: It focuses on the analysis of users' needs and then searches for technologies and meanings. Thus, this strategy aims at giving users what they ask for- leading to incremental improvements.

- Technology push innovation: This type of innovation reflects the dynamics of technological research and innovation. Here, the overlap between technology push and design driven innovation refers to shifts in technological paradigms within the context of change in socio-cultural regimes. For example, the introduction of Quartz watches in the '70s was integration of a breakthrough innovation in technologies (the introduction of semiconductors) and in meanings (shift in usage of watches from being jewels to being featured instruments).
- $\quad$ Design driven innovation: This strategy aims at radical change in the emotional and symbolic content of products. It brings changes in products' meanings and languages coupled with the comprehensive socio-cultural and technological changes. This type of innovation strategy is capable to create more value and strong brands comparatively which can hardly be imitated by the competitors. Thus, design-driven innovation secures sustained competitive advantage and long-term profit for the firm.

Design-driven innovation strategy balances three types of knowledge - users' needs, technological opportunities and product languages in a different way than other two strategies to generate competitive advantage (Verganti, 2003). Thus in the above stated example of Coldspot refrigerator, designer Loewy gave new meaning to that refrigerator through integrating contemporary aesthetics with materials and manufacturing technologies and satisfied customers' latent demand of choosing refrigerator as part of kitchen interior.

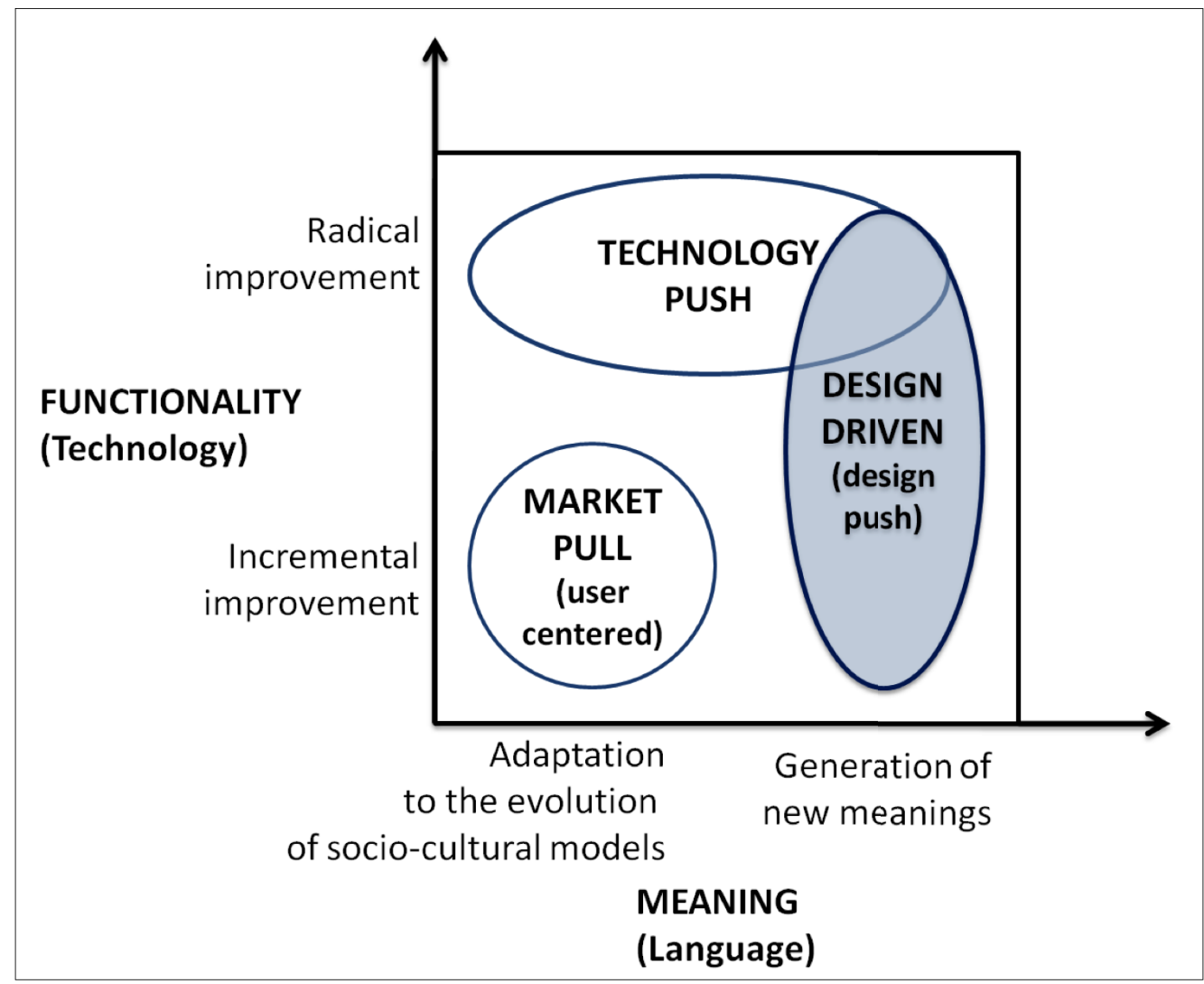

Figure I: Innovation Strategies (Source:Verganti, 2008)

ISSN: 07 I8-2724. (http://www.jotmi.org) 
In this report, design-driven innovation strategy has been further analyzed on the basis of some empirical data from automotive industry where design and innovation have been considered as two integral parts of the strategy of the firm to achieve sustained competitive advantage in rapidly changing dynamic market.

\section{Implication for strategic management}

According to Teece, Pisano and Shuen (1997), successful firms are those that have the capacity to "effectively coordinate and redeploy internal and external competences" to meet rapidly changing environment. Firms, that acknowledge the changing social and cultural environment and the opportunities to capture symbolic value, can deploy the skills and competencies of designers to bring meaningful products into the market.

Hence, the question is: what should be the role of design and designers in an organization? (Verganti (2003). In the past, the role of designers was mainly oriented towards the final stage of a product development. Once a product was in its final stage, designers were asked not only to make it more attractive to consumers but also to make it more ergonomic (Dell'Era and Verganti, 2007; Ravasi and Lojacono, 2005).

Nowadays some scholars are emphasizing on the importance of involving designers from the very starting point of the innovation process (Verganti, 2003). Others go even further by suggesting that the design-driven innovation should be considered as a "core capability and a primary source of competitive advantage" (Ravasi and Lojacono, 2005). For this reason, nowadays a designer's place in an organization has been given much attention and his/ her status inside the firm has been increased significantly. Examples include the promotion of designers in some firms to the post of vice-president (Ravasi and Lojacono, 2005). Besides, "entrepreneurial thinking" i.e., independent thought and action is encouraged in many organizations like $3 \mathrm{M}$, Hewlett-Packard and the Virgin Group to create the climate of innovation; some organizations develop autonomous work unit called 'Skunkworks' to motivate creative thinking and brainstorming, but in many cases it is a big challenge to guide this autonomous team towards success (Quinn, 1992; Dess and Lumpkin, 2003).

Companies who really want to capitalize on design and designdriven innovation as sources of competitive advantage should make them one of their core competences. Prahalad and Hamel (1990) define core competences as a firm's capacity to "co-ordinate diverse production skills and integrate multiple technologies". A good example of a firm which has succeeded in this field is Ducati - the Italian motorcycle manufacturer. By integrating designers' skill with its other core competences, as for example, R\&D and quality control, the firm has managed to build authentic products that correlate with the need of social status of its young customers (Gavetti, 200I). The concept of core competences has immense influence on managerial thinking for long term growth rather than short term growth through rapid expansion with diversified strategic business units (SBUs) (McGrath, 20 I0; Prahalad and Hamel, 1990). The human knowledge or skill embodied in core competence needs to be acknowledged and nurtured to increase consumers' perceived value in end products (for example - Honda's expertise in engine) (Prahalad and Hamel, 1990). But in most cases top managers in SBUs fail to figure out their corporate asset to be deployed and thus they restrict the innovation process (McGrath, 2010; Prahalad and Hamel, 1990). Technical know-how can be outsourced but intellectual asset acquired by harnessing competences of employees across the organizational boundary is inimitable and always widens the boundary of innovation. Thus, after the 2 nd world war Japanese car maker - Toyota has secured relentless improvement over imprisoned competences of American carmarkers (Hamel, 2009; Prahalad and Hamel, 1990). Even today consumers are having unique experience of each BMW model, because of the passionate culture of innovation in the BMW Group focused for aesthetics, dynamics, precision and perfection through strong synthesis across group's R\&D network in five countries ("Research and Development Network (BMW)", 2010).

According to Ravasi and Lojacono (2005), to adopt designdriven strategy within the operational structure of the firm, managers need to recognize the value of experimentation and give designers all the resources and required freedom to explore new forms and concepts autonomously. However, this action sometimes backfires and puts the firm at the verge of economic crisis, for example, Bang and Olufsen - the Danish company that manufactures audio-visual products, experienced the worst ever crisis by focusing on award winning designs rather than commercially successful products. Since managers pay less focus on product or brand policies and empower designers to control design center as the core focal point of the firm, this loss of control increases the risk of a divergence between designers and the market (Ravasi and Lojacono, 2005). Thus, balancing the role of each actor within the firm is very crucial to develop strategically relevant products to achieve competitive advantage through design-driven innovation strategy.

Since design is considered as a symbolic way of selfexpressive value or personality (Keller, 1993), it not only works as a functional differentiation but also alleviates emotional value creation (Noble and Kumar, 2008). In a well-structured organization, design is a team effort of designers, engineers and researchers skilled in ethnographic or observational research (Veryzer and Mozota, 2005). It 
can contribute competitive edge to the company (Kotler, 2003) only when the total product outcomes customer satisfaction (Noble and Kumar, 2008; Veryzer and Mozota, 2005). In automotive industry, a designer play critical role as an integrator by combining both internal and external information within the process (Fujimoto, 1991) and also works as a catalyst to establish emotional bondage with consumers by embodying their desires within technological potentials (Veryzer and Mozoto, 2005). With the pace of time, certain automakers like the BMW group, Ford or even Toyota have successfully encrypted social demand and consumers' emotion in different car models through harmonizing internal competencies with external changes and have achieved upswing in sales and brand loyalty (Noble and Kumar, 2003; "Research and Development Network (BMW)", 2010; Gartman, 2004). Now, questions may be raised whether all companies possess enough resources to strive for design-driven innovation and the probable answer resides in the evolution of 'open-innovation' (Chesbrough, 2003) or 'value co-creation' (Katila \& Ahuja, 2002; Laursen \& Salter, 2006; 'Business Innovation Observatory', 2014) business model concepts as discussed by several researchers and practiced by renowned organizations like the BMW Group.These wings of research surely pave the potentials of design-driven innovation strategy in different angle.

\section{Innovation strategies in automotive industry and dominance of design}

Since the manufacturing of the first car, product innovation has been a hallmark of the automotive industry to stay ahead or simply to survive in this fiercely competitive and dynamic market ("IBM", 2006). Historical research works of innovation pattern and industrial dynamics in the automotive industry shows the trend for continuous improvement based on process innovation, incremental product innovation and adoption of new component technologies to add new features (Magnusson and Berggren, 20I I). Over the time, the language of automotive styles have gradually been changed from the boxy vehicles of the 1970s and 1980s to the curvy, flowing shapes of 1990s, to today's complex, prismatic and edgy shapes (Verganti, 2009 p. 46).

Today, the entire automotive industry is undergoing a renaissance in both exterior and interior design aspects to make each vehicle more distinctive by appearance to new generation customers, who prefer to choose a car to resonate with his/her personality rather than considering the quality and performance of the car (Buss, 2004). The German car manufacturer Audi has considered delighting customers as one of its primary goals. "Can you remember the last time that someone fulfilled one of your wishes even before you had voiced it" - as said by Audi's CEO (“Audi”, 20I2), indicates perhaps that Audi is being a pioneer in the design-driven innovation. Other examples include the radical curvature of the Nissan Murano "crossover" or the chiseled line of new Cadillac, the racing stance of the Ford GT sports car or the chock-a-block utilitarianism of the Honda Element sportutility vehicle - all together today's car models express more visual distinctiveness than baby-boomer consumers have ever experienced. Hence, the design has become more of a differentiator for today's target customers (Buss, 2004). Design-driven innovation strategy can generate long-lived product even at low-end market, as for example, the Fiat Panda city car which has attracted the users through its meaningful approach rather than functionality and stylish features (Verganti, 2009, p. 105).

"It's an exciting time for car design and for the industry in general, because both consumers and the car companies are ready to see more chances taken out there. People are kind of sick of the same old thing, and they're looking for something new."

- Chris Chapman, Director of

DesignWorks USA, California (as cited in Buss, 2004).

KPMG's Global Automotive Executive Survey (2012) has revealed environmental concerns, growing urbanization and changing customer behavior as the key issues influencing the global automotive industry. According to this survey, customers specifically the young generation people are becoming less certain in their tastes and attitudes towards vehicles where only cutting-edge technology are not enough, but also nicer, safer and greener issues influence in making purchase decision ("KPMG", 20I2). Consumer behavior is changing across focusing the differentiating aesthetic appearance of the car rather than the basic materialistic functions which is focused by KPMG's Global Automotive Executive Survey (2012) as "The world is moving from car ownership to car usership." In such context, design driven innovation strategy has potential to be followed by the companies in the automotive industry to create sustained competitive advantage through balancing customers' need, technological opportunities and product meaning. Today's customers' expectations, more specifically young generation's expectations are going through radical change. Their emotional association with car is expressed by few words like - 'affordability', 'work-life balance', 'social networking', 'environment', 'style' and more importantly 'brand image' ("The highway to growth", 2013;"NNext generation car buyer study", 2013). According to several automotive consumer surveys by organizations like - PWC,Autotrader.com and Deloittte ("The highway to growth", 2013;"Next generation car buyer",2013; "Annual Gen $Y$ automotive survey", 2012; "Global Automotive Consumer Survey", 20I4), the generation $Y$ (ranging in age from 19-3I) or millennials represents a large and highly important consumer segment to be focused after baby boomer generation; which has already become owner of $25 \%$ of all new vehicles sold in 
the U.S. in 2012 and also will represent I5\% of the market in Germany by 2020.This Gen Y consumers want to use their car as a mean to represent their personality, accomplishment and sense of lifestyle or luxury and brand image while driving in the road; through a combination of quality, latest technology and workmanship ("Next generation car buyer", 2013;"Annual Gen Y automotive survey", 20I2). At the same time, this consumer segment also very much concern about their affordability and will not hesitate to give up personal transport due to increased cost ("Global Automotive Consumer Survey", 2014). Thus, automotive industry has become more challenging and competitive with diversified demands for companies.

"Auto manufacturers have an opportunity to develop innovative and low-cost personalization options for this powerful consumer segment."

\section{- Joe Vitale,Global Automotive Sector Leader,}

Deloitte Touche Tohmatsu Limited

(“Annual Gen Y automotive survey”, 20I2).

But still fewer automotive companies have well-structured roadmap in collaboration with stakeholders for innovation and also have clearly defined strategy to take the call; and others are juggling efforts to balance their innovation portfolio ('The highway to growth', 2013). Due to the dynamic nature of the industry, it is very difficult to quantify the success of a specific strategic move rather than analyzing situations over periods, as companies are taking a series of strategic actions to face competition's maneuvers (D’Aveni, 1998).

During the evolution of automotive industry, while some front-line Japanese companies compared to other U.S. companies have started to capitalize time as a strategic weapon to achieve competitive advantage in productivity, quality and innovation within technology-intensive industry (Stalk, 1988), Toyota has become the benchmark for other companies within the industry for its trend setting strategic invention - 'lean production system' (Grant, 2010, p. 138,2|4). Besides, ensuring continuous improvement and quality, Toyota is now also focusing on the synthesis of innovation and design through a new car making policy aimed at making ever-better cars ("Toyota", 20I2). The concept of 'j-factor', based on unique Japanese values and aesthetics, is positioned as a core element of the DNA of 'Toyota Design'; for example, Toyota iQ is a small, compact and innovative car inspired by the 'Miniaturization' specialty of Japanese craftsmanship. Through its innovative design, Toyota always wants to create value by satisfying social causes and responsibilities. ("Toyota Design”, 20I2a). This design award winning ultra-compact vehicle is aimed for urban people who want premium and vibrant design with rationality and also with functionality such as, reducing $\mathrm{CO} 2$ emissions
(“Toyota Design”, 20I2b).Toyota satisfies its customers with not only quality cars but also a good range of differentiating and appealing vehicles starting from functional to lifestyle category. As it is expressed by the General Manager of the Toyota's global design division, "People expect more from their vehicles, not only in a functional sense, but also from an emotional and self-expressive point of view" (Humphries, n.d.). In this part of this study, innovation strategies of Toyota for its diversified product line will be analyzed shortly based on Verganti's innovation strategy framework to understand its strategic movement through certain well-known and breakthrough brands.

To achieve ultimate goal of making better car, Toyota has reformed its development structure by dividing car-making into four zones and the objective is to come up with better cars from each zone by combining the design and performance features to meet customers' expectations ("Toyota", 2012). The concept of these four zones is analyzed here briefly with an idea to explore certain brands/ models of Toyota vehicle later on within the framework of innovation strategy.

According to the aim of this short report, only few brands and models of Toyota vehicles are analyzed through Verganti's (2003) framework on 'knowledge drivers in different modes of innovation'. The objective of this short graphical analysis is to have a view of probable strategic movement across certain brands of Toyota vehicles where three knowledge drivers - user's needs, technological opportunities and product language are considered. 


\begin{tabular}{|c|c|c|c|c|}
\hline Zone: & $\begin{array}{l}\text { Cars specialized to meet } \\
\text { tastes and car sense }\end{array}$ & $\begin{array}{l}\text { Fleet and personal trans- } \\
\text { formational vehicles }\end{array}$ & $\begin{array}{l}\text { Vehicles with social pur- } \\
\text { pose: buses etc. }\end{array}$ & Next generation vehicles \\
\hline $\begin{array}{l}\text { C ○ n - } \\
\text { cept: }\end{array}$ & $\begin{array}{l}\text { Sports cars and luxu- } \\
\text { rious cars with intel- } \\
\text { ligent and innovative } \\
\text { engineering; stylish } \\
\text { and contemporary } \\
\text { interior and exterior } \\
\text { designs; colors load- } \\
\text { ed with attitude and } \\
\text { personality; designer's } \\
\text { car around the globe. } \\
\text { Brands - Toyota } \\
86 \text {, Aurion, Lexus }\end{array}$ & $\begin{array}{l}\text { Small car like SUV*, } \\
\text { RV*, 4WD* with ad- } \\
\text { vanced safety technology } \\
\text { and features designed for } \\
\text { comfort and convenience. } \\
\text { Brands - RAV4, } \\
\text { Land Cruiser, } \\
\text { Kluger, Prado } \\
\text { More fuel efficient, } \\
\text { Front-engine } \\
\text { smaller } \\
\text { Front-drive(FF) passenger } \\
\text { vehicle; } \\
\text { Corolla }\end{array}$ & $\begin{array}{l}\text { Utility vehicles and } \\
\text { vans focusing on } \\
\text { comfort and ver- } \\
\text { satility, more space, } \\
\text { great acceleration for } \\
\text { smooth turning and } \\
\text { easy parking options; } \\
\text { Brands- Coaster, } \\
\text { HiAce, HiLux }\end{array}$ & $\begin{array}{l}\text { IMV* series: localized } \\
\text { and customized ve- } \\
\text { hicles for emerging } \\
\text { market based on the } \\
\text { concept- 'customer } \\
\text { first and not product } \\
\text { first' } \\
\text { Brand - Etios, }\end{array}$ \\
\hline
\end{tabular}

Table I: Concepts of Toyota car-making zones

*Note: SUV = sport utility vehicle, $R V=$ Recreational vehicle, $4 \mathrm{WD}=$ four-wheel-drive, $I M V=$ Innovative International Multi-purpose Vehicles (Source: “Toyota”, 20I2;“Toyota traditions", n.d.) 

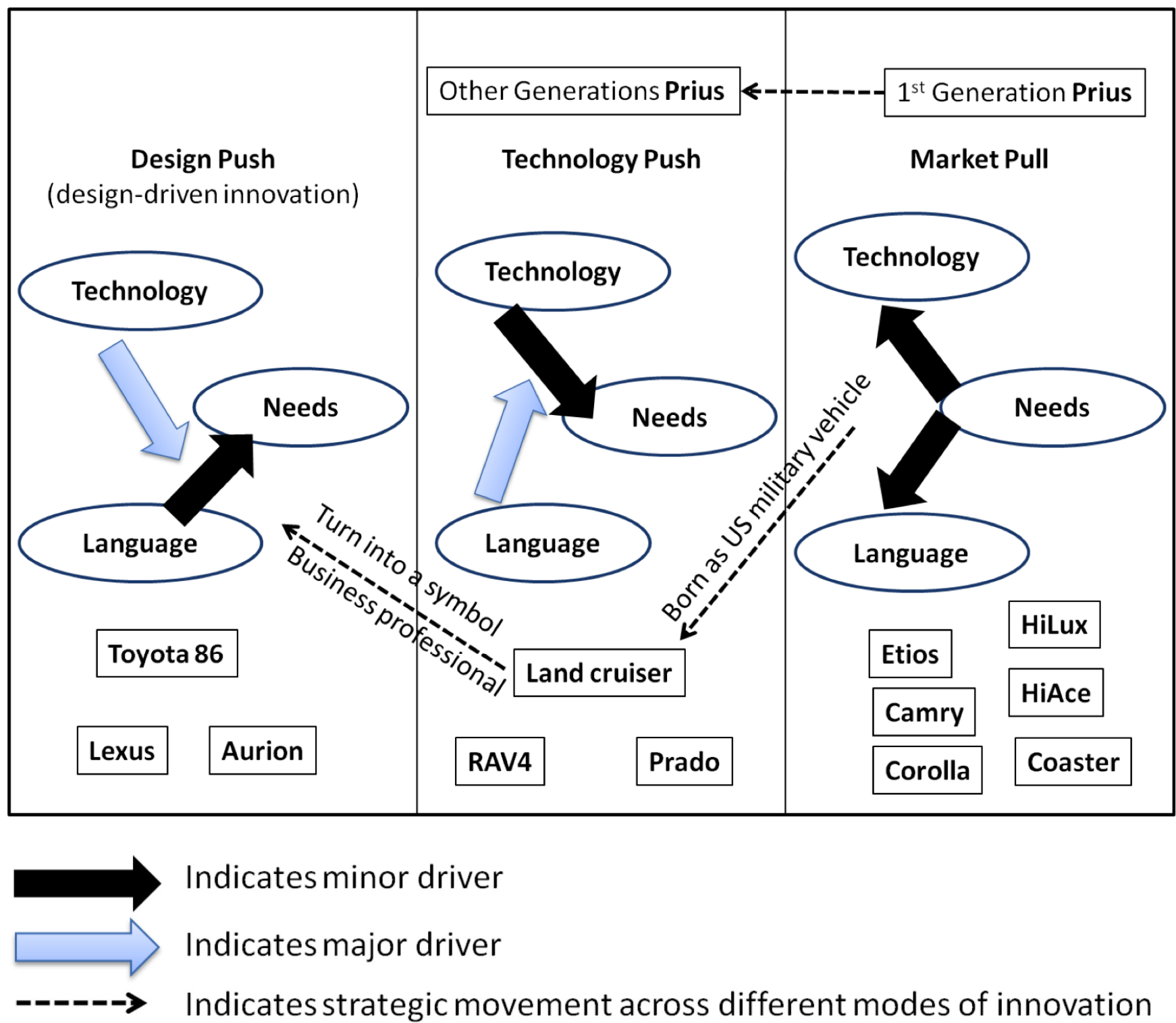

Indicates minor driver

Indicates major driver

Indicates strategic movement across different modes of innovation

Figure 2: Different modes of innovation strategy for Toyota brands and models considering knowledge drivers.

(Source:Adapted from Veganti, 2003; www.toyota.com) 
Over the years, Toyota has adopted different innovation strategies with the Market-Pull strategy being its main innovation strategy-

"If I were asked to give one example of something that Toyota can be proud of, I would say that it is continuously striving to respond to customer needs"

- Head,Toyota global design division (Humphries, n.d.)

Toyota has launched the first generation of the Prius brand as its response to growing environmental concerns. Initially this hybrid automobile has been the outcome of market pull innovation strategy. Later on, 2nd and 3rd generation Prius models have been designed considering consumers' both growing demands on more functional efficiency and latent demand for futuristic design instead of old 'boring' image of environmentally friendly automobile ("Toyota Design”,20I2b). However, over the years, with remarkable improvements in the hybrid technology, Toyota has managed to push the new generations of the Prius brand to the automobile market and has gradually applied different innovation strategies for different models of car. Similarly the Land Cruiser brand has been built and designed as a heavy duty vehicle to fulfil the requirements of the U.S. military and police agencies ("Land Cruiser", n.d.), as an outcome of the market pull strategy. Since then, the innovation strategy for this brand has evolved and with the pace of time the brand with different models, has become more sophisticate and versatile for different segments of customers. Today, perhaps due to design driven innovation the brand - Land Cruiser - 'once born as military vehicle' has been turned into a symbol of power and status for the high profile business professionals. Thus with shift in technology and cultural variables, consumers' perception or acceptation of product designs undergo changes, which need to be addressed by marketers at the right time for their survival (Bloch, 1995).

\section{Discussion and Conclusion}

From the above analysis it is revealed that, design is a strategic resource to bring more value to a product. Furthermore, for firms adopting a design-driven innovation strategy, it could not only mean bringing more value to customers but also mean taking the competition race to the next level where competition becomes less fierce. In other words, it allows firms to go from "Red Oceans" where the market is shrinking to "Blue Oceans" where opportunities are unlimited (Kim and Mauborgne, 2005). In today's competitive environment, most firms consider innovation as an essential part to sustaining competitive advantage (Dess, Lumpkin and Eisner, 2009) ; and it is clearly expressed in legendary management guru and research scholar - Peter Drucker's statement -'An established company which, in an age demanding innovation, is not capable of innovation is doomed to decline and extinction' (Drucker, 1985). Despite of its importance, some companies are reluctant to spend on both time and money for innovation, compromising company's bottom-line (Steere, 1997), as the innovation process is very challenging and uncertain until ultimate goal is achieved (Dess, Lumpkin and Eisner, 2009). In a particular industry one company's radical innovation could be another company's incremental innovation (Canabou, 2003 as cited in Dess, Lumpkin and Eisner, 2009). In such context designers play critical role to blend customers' need with opportunities from science and business in order to manufacture a culturally relevant, economically productive and ecologically sustainable product (Esslinger, 20I I). Innovation based on a company's dynamic capability and its management is definitely an imperative action for any company to adapt to rapid environment and consumer need.

Among many other industries, automotive industry is Europe's biggest investor in R\&D sector which is also same in Japan, and according to European Patent Office Data for 2013, the highest number of patent have been filed by automotive sector at European Patent Office (European Automobile Manufacturers Association [ACEA], 2013). These facts reveal the emergence of continuous innovation in the automotive industry. According to the consulting firm - Oliver Wyman's study on innovation in automotive industry (Oliver Wyman, 2007), ongoing specialization in engineering among manufacturers might cause decline in technological product differentiation and thus manufactures need to focus on innovation effort to create brand defining features for sustained competitive position. Design-driven innovation strategy is already being pursued by firms in the automotive industry. While the automotive industry has been in the mature stage in its industry lifecycle (Magnusson and Berggren, 20l I), car manufacturers are using this innovation strategy, among others, to differentiate themselves from competitors. Design-driven innovation incurs extra cost to consumers, and considering this cost pressure, industry experts have analyzed that within 2015 Own Equipment Manufacturers (OEMs) are planning to offer low-cost innovative cars using revolutionary materials and low cost module designs (Oliver Wyman, 2007). Outsourcing of innovation design ideas or open innovation platform can balance cost involvement in this capital-intensive industry; where outsourcing from industry trendsetters such as Pininfarina, Valmet, Karmann or other companies will also add value to particular car brand. Collaboration with innovation partners and effective management of R\&D team might lead an attempt of design-driven innovation toward success. Each company's dynamic capability actually defines its strategy for innovation management. 
Few decades ago, automotive industry could offer only certain varieties of cars to satisfy its customers' functional need where any car with extra features could create a bang in the market and sustained long-term position. But today this technology-intensive industry is at such a stage in the market that consumers are bombarded with tyranny of choices from different automakers. Advanced technological strength can no longer be considered as a sole reliable source of sustained competitive advantage. There is a shift in the consumer behavior pattern which might be dominating the purchase decision. Consumers think that they might get all technical and functional features as standard and then they move forward to get something extra from the aesthetic appearance of a car to match it either with their personality or social status. As nowadays transportation is not the only reason for the customers to buy a car, they are even ready to pay more extra for appealing color or for a single distinctive curvature on the car. Today certain models of SUV have turned into the symbol of class for the innovative sporty look though these are mostly utility vehicles. Thus, design driven innovation strategy could be the potential source for an automaker to achieve sustained competitive advantage and also to give new dimension of competition in the industry. According to Verganti (2008), though design-driven strategy plays crucial role in innovation strategy within the design-intensive industry, it is still unexplored. Hence, this area of strategy to achieve competitive advantage might have more research potential to accelerate a mature industry- like the automotive one. In this review article, authors have attempted to toss their ideas on the implication of design-driven innovation as a differentiation strategy in the automotive industry through some industry examples and analysis; and hope that it might motivate other scholars to explore this fertile research territory and test these ideas.

\section{References}

ANNUAL GENY.AUTOMOTIVE SURVEY. (20I2). Executive summary of

key themes and findings. Retrieved June 10,2015 from https:// www2.deloitte.com/content/dam/Deloitte/de/Documents/ manufacturing/Annual_Gen_Y_20I2_2_web.pdf

AUDI. (20I2). 20II Annual report. Retrieved October 23, 2012 from http://www.audi.com/com/brand/en/company/ investor_relations/financial_reports/annual_reports.html

BARNEY,J.( (199I). Firm resources and sustained competitive advantage. Journal of Management, 17 (I), 99-120.

BLOCH, P. H. (1995). Seeking the ideal form: Product design and consumer response. Journal of Marketing;Vol. 59(3), 1629

BOUCHENOIRE, J. L. (2003). Steering the brand in the auto industry. Design Management Journal, I4 (I), I0-18.

BOWMAN, C., Ambrosini, V. (2003). How the resourcebased and the dynamic capability views

of the firm inform corporate-level strategy. British Journal of Management, 14 (4), 289-303.

BRUNSON, J. (2014). Scooty Girls: Mobility and Intimacy at the Margins of Kathmandu. Journal of Anthropology , 79 (5), 610-629.

BUSS, D. (2004). Design shifts drive auto brands. Brandchannel. Retrieved October 23, 2013 from http://www.brandchannel. com/features_effect.asp?pf_id=24I

BUSINESS INNOVATION OBSERVATORY. ( 20I4). Design for innovation, smart living and innovative business models; how to scale-up success? Retrieved June 15, 2015 from http://ec.europa.eu/enterprise/policies/innovation/policy/ business-innovation-observatory/files/02-design-forinnovation-smart-living-and-innovative-business-models.pdf

CHANDY, R., Tellis, G. (2000). The incumbent's curse?Incumbency, size, and radical product innovation. Journal of Marketing, 64 (3), I- 17.

CHESBROUGH, H.W. (2003). Open innovation: The new imperative for creating and profiting from technology. Harvard Business School Press, Boston.

ISSN: 07I 8-2724. (http://www.jotmi.org) 
DE VISSER, M., de Weerd-Nederhof, P., Faems, D., Song, M., Van Looy, B., Visscher, K. (2010). Structural ambidexterity in NPD processes: A firm-level assessment of the impact of differentiated structures on innovation performance. Technovation, 30 (5/6), 29I-299.

DELL'ERA, C., Verganti, R. (2007). Strategies of innovation and imitation of product languages. Journal of Product Innovation Management, 24, 580-599.

DAVENPORT, T., Leibold, M., Voelpel, S. (2006). Strategic management in the innovation economy- Strategy Approaches and Tools for Dynamic Innovation Capabilities. Wiley, New York.

DESS, G. G., Lumpkin, G. T. (2003). Strategic management: Creating competitive advantages. The McGraw-Hill Irwin, New York.

DESS, G. G., Lumpkin G. T., Eisner, A. B. (2009). Strategic management: Text and cases. The McGraw-Hill Companies Inc., New York.

DOBSON, J. (2007). Aesthetics as a foundation for business activity. Journal of Business Ethics, 72 (I), 4I-46.

DRUCKER, P.F. (1985). Innovation and entrepreneurship: 2000. Harper and Row, New York.

DUCATI. (2012). Authentic Italian performance. Retrieved October 20, 2012 from http://www.ducati.com/company/ profile/index.do.

D'AVENI, R. A. (1998). Waking up to the new era of hypercompetition. The Washington Quarterly, 2 I (I), I83195.

D'AVENI, R. A., Dagnino, G. B., Smith, K. G. (2010). The age of temporary advantage. Strategic Management Journal, 3 I (13), | 137|-| 385.

EISENHARDT, K. M., Martin, M. (2000). Dynamic capabilities: what are they?. Strategic Management Journal, $2 \mathrm{I}$ (I0/II), II05-II2I.

ESSLINGER, H. (20II). Sustainable design: Beyond the innovation-driven business model. Journal of Product Innovation Management, 28 (3), 40 I-404.

EUROPEAN AUTOMOBILE MANUFACTURERS ASSOCIATION (ACEA). (20I3). The automobile industry pocket guide. Retrieved April 10, 2014 from http://www. acea.be/uploads/publications/POCKET_GUIDE_13.pdf.
GARTMAN, D. (2004). Three ages of the automobile: The cultural logics of the car. Theory, Culture \& Society, $2 \mathrm{I}(4 / 5)$, 169-195.

GAVETTI, G. (200I). Case 16: Ducati. Harvard Business School, Case 9-70I-I32.

GLOBAL AUTOMOTIVE CONSUMER SURVEY. (2014). Retrieved June 10, 2015 from http://www2.deloitte.com/ content/dam/Deloitte/us/Documents/manufacturing/usauto-global-automotive-consumer-study-100914.pdf

GRANT, R. M. (2010). Contemporary strategy analysis (7th ed.). John Wiley and Sones Ltd, Chichester.

HAMEL, G. (2009). The why, what, and how of management innovation. Harvard Business Review, 84 (2) , 72-84.

HANCOCK, P. (2005). Uncovering the semiotic in organizational aesthetics. Organization, I 2 (I), 29-50.

HUMPHRIES, S. (n.d.). Steering Toyota design from a global perspective. Toyota Design. Retrieved October 24, 2012 from http://www.toyota-global.com/innovation/toyota_ design/voice_of_design/0l.html

IBM GLOBAL BUSINESS SERVICES. (2006). Driving innovation: Five opportunities for the automotive industry. Retrieved October 18, 2012 from http://www-05.ibm.com/ de/automotive/downloads/innovation_automotive_pov.pdf.

KATILA, R., Ahuja, G. (2002). Something old, something new: A longitudinal study of search behavior and new product introduction. Academy of Management Journal, 45 (6), I I831194.

KELLER, K. L. (1993). Conceptualizing, measuring, and managing customer-based brand equity. Journal of Marketing, $57(I), I-22$.

KIM, W. C., Mauborgne, R. (2004). Blue ocean strategy. Harvard Business Review, 82 (I0), 76-84.

KPMG INTERNATIONAL. (20I2). KPMG's global automotive executive survey 20I2. Retrieved October 16, 2012 from http://www.kpmg.com/GE/en/lssuesAndlnsights/ ArticlesPublications/Documents/Global-automotiveexecutive-survey-2012.pdf.

KOTLER, P. (2003). Marketing Management (I lth ed.). Prentice-Hall , Upper Saddle River, NJ. 
LAND CRUISER. (n.d.). Origin. Retrieved October 24, 2012 from http://www.toyota-global.com/showroom/vehicle_ heritage/landcruiser/origin/

LAURSEN, K., Salter,A. (2006). Open for innovation:The role of openness in explaining innovation performance among U.K. manufacturing firms. Strategic Management Journal, 27 (2), $|3|-\mid 50$.

MAGNUSSON, T., Berggren, C. (20I I). Entering an era of ferment - radical vs incrementalist strategies in automotive power train development. Technology Analysis and Strategic Management, 23 (3), 3।3-330.

McGRATH, R. G. (2010). Business models: A discovery driven approach. Long Range Planning, 43 (2-3), 247-26I

MOONEY, A. (2007). Core competence, distinctive competence, and competitive advantage: What is the difference?. Journal of Education for Business, 83 (2), II0II5.

NEXT GENERATION CAR BUYER STUDY. (20I3). Executive Summary, AutoTrader. Retrieved June 15, 2015 from http://www.autonews.com/assets/PDF/CA90353823. PDF

NOBLE, C. H., Kumar, M. (2008). Using product design strategically to create deeper consumer connections. Business Horizons, 5 I (5), 44 I -450

O'CONNOR, G., de Martino, R. (2006). Organizing for radical innovation: An exploratory study of the structural aspects of RI management systems in large established firms. Journal of Product Innovation Management, 23 (6), 475-497.

OLIVER WYMAN. (2007). Car innovation 2015. Retrieved April 07, 2014 from http://www.oliverwyman.com/content/ dam/oliver-wyman/global/en/files/archive/pr/CI20I5_Dig_ eng.pdf

PRAHALAD, C. K., Hamel, G. (1990). The core competence of the corporation. Harvard Business Review, 68 (3), 79-9I.

QUINN, J. B. (1992). Intelligent Enterprise. Free Press, New York.

RAVASI, D., Lojacono, G. (2005). Managing design and designers for strategic renewal. Long Range Planning, 38 (I), $5 \mathrm{I}-77$.

RAVASI, D., Rindova, V. P. (2004). Creating symbolic value: A cultural perspective on production and exchange. SDA Bocconi Working Page No.I I I/04.
RESEARCH AND DEVELOPMENT NETWORK (BMW). (20I0). From the Original Idea to Final Innovation in a Networked World. Retrieved June 5, 2015 from http://www. bmwgroup.com/publikationen/e/20I0/pdf/FIZ_20I0_en.pdf

ROLEX. (n.d.). Rolex watchmaking. Retrieved October 23, 2012 from http://www.rolex.com/en\#/world-of-rolex/ about-rolex/904l-steel

STALK Jr, G. (1988). Time -The Next Source of Competitive Advantage. Harvard Business Review, 664I- 665I.

STREERE Jr., W.C., Niblack, J. (1997). Innovation: Break through thinking at 3M, Dupont, GE, Pfizer, and Rubber-maid (R. M. Kanter, ed.) . HarperCollins, New York.

TEECE, D. J., Pisano, G., Shuen,A. ( 1997$)$. Dynamic capabilities and strategic management. Strategic Management Journal, 18 (7), 509-533.

THE HIGHWAY TO GROWTH. (20I3). Strategies for automotive innovations. Retrieved June 13,2015 from http:// www.pwccn.com/webmedia/doc/635290I845I6600345_ consulting_auto_highway_feb20I4.pdf

THE VISION OF DANISH DESIGN 2020 COMMITTEE. (20II). Retrieved October 18, 2012 from http://www. google.com/url?sa $=$ tandrct $=$ jandq $=$ andesrc $=$ sandsource $=$ we bandcd $=2$ andcad $=$ rjaandved $=0$ CCYQFjABandurl=http $\% 3 \mathrm{~A}$ \%2F\%2Fwww.beda.org\%2Findex.php\%2Fresources\%2Fitem \%2Fdownload\%2F29andei=-oWIUMDgl6aO4gSkllClCwand usg=AFQjCNGvIfs_cET5qxXNxILGpJk04i7PHQ

TOYOTA. (2012). Annual Report 2012. Retrieved October 22, 2012 from http://www.toyota-global.com/investors/ir library/annual/pdf/20I2/ar I2_e.pdf

TOYOTA DESIGN. (20I2a).J-Factor:Toyota design is moving forward. Retrieved October 22, 2012 from http://www. toyota-global.com/innovation/toyota_design/j_factor/

TOYOTA DESIGN. (20I2b). Design Awards-2008. Retrieved June 7,20I5 from http://www.toyota-global.com/showroom/ toyota_design/award/2008/

TOYOTA TRADITIONS. (n.d.). Innovation. Retrieved October 20, 2012 from http://www.toyota-global.com/ company/toyota_traditions/innovation/

VERGANTI, R. (2003). Design as brokering of languages:The role of designers in the innovation strategy of Italian firms. Design Management Journal, 14 (3), 34-42.

ISSN: 07 I8-2724. (http://www.jotmi.org)

Journal of Technology Management \& Innovation (c) Universidad Alberto Hurtado, Facultad de Economía y Negocios. 
VERGANIT, R. (2008). Design, meanings and radical innovation: A meta-model and a research agenda. Journal of Product Innovation Management, 25, 436-456.

VERGANTI, R. (2009). Design driven innovation- Changing the rules of competition by radically innovating what things mean. Harvard Business Press, Boston.

VERYZER, R.W., de Mozota, B. B. (2005). The Impact of UserOriented Design on New Product

Development:An Examination of Fundamental Relationships!. Journal of Product Innovation Management, 22(2), I28-I 43.

VOGEL, C. M. (2009). Notes on the evolution of design thinking:A work in progress. Design

Management Review, 20 (2), 16-27.

ZOLLO, M., WINTER, S. G. (2002). Deliberate learning and the evolution of dynamic capabilities. Organization Science, 13, 339-35|.

ZAHRA, S. A., George, G. (2002). The net-enabled business innovation cycle and the evolution of dynamic capabilities. Information Systems Research, I3 (2), I47-I5I. 